\title{
CASE STUDY ON HOLISTIC ASSESSMENT OF THE RELATIONSHIP BETWEEN CITY AND SQUARE
}

\author{
Duygu TURGUT (1) * \\ Department of Architecture, Erciyes University, Kayseri, Turkey
}

Received 11 October 2019; accepted 13 July 2020

\begin{abstract}
While the squares have been in the network of relations with the political, social and religious structure of the society since the early days of history, today, they have been associated with the cars, speed and technology in the process formed with the modernization movement. In some squares, there are tramways, public transportation routes and stops, and there are also motor vehicles. The squares have turned into places where there is a continuous flow with fast traffic except for waiting at the bus stops and railway station. With this change, our needs also changed, and with the introduction of motor vehicles in our lives, the squares remained as neglected urban spaces in an effort to create a transportation network. The use of the squares belongs to the period in which people have habit of being together, but now squares use belongs to a period in which we are not together even if we are side by side. Within the scope of this study, nowadays, approaches and practices for the squares that is an urban space in the world have been investigated. According to the results of sections, the criteria for evaluating the completeness of the city-square relationship in today's conditions are set out in a table. The selected from the Trafalgar Square, Bryant Park and Taksim Square samples consecutively examined in the context of these criteria.
\end{abstract}

Keywords: square, urban landscape, public space, urban public space, square analysis, city-square relationship, Trafalgar Square, Bryant Park, Taksim Square.

\section{Introduction}

The present study begins with analyzing the place and meaning of the squares as public spaces in today's cities. It was wondered how a process the squares have passed through and gained their current position. The physical, social, spatial, and functional characteristics of squares as urban public space were questioned. The squares have been related to the markets, commerce, religion, politics, and social life in the past, whereas they are now related to the traffic, transportation, and speed. The change in needs and the introduction of motor vehicles in our lives turned squares into neglected urban spaces due to the efforts aiming to create the transportation network. First of all, in order to discuss the problems related with the "square", the relationship between square and city should be considered from a holistic perspective. The keywords were determined making use of the theoretical studies and the approaches to square throughout the world, and the criteria enabling the analysis of holism of city-square relationship in today's world are presented in the table (Table 1). Making use of the criteria set in this study, the analyses were conducted over a square chosen as example and the current position of the phenomenon "square" was questioned.

\section{Theoretical studies}

In examining the square as an urban public space, it is important to define the concepts of space, urban space, city, successful city, urban design, private spaces, and public spaces. Thus, in order to define the city-square relationship, these conceptual contexts were systematically analyzed here. Urry (1999) has related the space to the society by stating that "The spatial one shall not be separated from the social one in the way creating a series of different general rules. This is because space solely has no effect. The importance of spatial relationships depends on the private character of relevant social objects". The author considers the space as a living organism harmonized with the meaning, intellectual power, and the marks of its background. Yücesoy (1999) aimed to reveal the conjunction points between the methods of "understanding", "examining", and "interpreting" the city and urban space, and defined the space by thinking that it has an identity: "Five axes can be specified for analyzing the processes and relationships between elements of spatial identity: The formal axis includes all the physical structures (topography, constructed environment, landscaping elements, and

*Corresponding author. E-mail: m.duyguturgut@gmail.com 
others) constituting the urban space. The functional axis, however, consists of the types of activities and usages in the urban space, as well as the relationships between them. The meaning and perceptual axis includes the behaviors of those living in the city and using the urban space to space, as well as the presentations, meaning characteristics, and spatial communication characteristics of the urban space. The historical, cultural, and social axis consists of social structure, types of space usages, and changing space editing". The concept of "space" is very important to define and understand the concepts of city and urban space.

The cities are the habitats, where the people gather and maintain their social and societal lives. Union of people within the frame of common ideals, types of interdependence of individuals and social classes, integration ability, sense of solidarity, and amenities have emerged in the cities. Many researchers have considered the concept of city as follows.

Montgomery (1998) stated that "the city is a constructed complexity phenomenon". From another perspective, the city is a continuity that carries the traces of past to today and continues with this process. According to Erzen (2005), the city as a spatial structure is an arena incorporating anthropogenic phenomena and the historical continuity emphasizing the anthropogenic meanings gains a physical form in the city. As stated by Barthes (1997), this continuity can be defined as "The city is a discourse and it is the language of those living in that city. It carries the symbols and marks of social life between the generations."

An event occurring or an object existing in the outer environment is engraved in the subconscious through perception in a simple form by using a perception method. In perceiving the city and evaluating it by engraving in subconscious, Lynch (1960) analyzed the elements constituting urban image and established the memory map based on these elements. According to Lynch (1960), there are five main elements symbolizing the city; "borders, regions, roads, nodal points, and triangulations". Lynch (1960) emphasized that it is not easy to make sense out of the changes in urban shapes because many individuals having different backgrounds have different images about the same physical form. However, he has stated that a city can be perceived using these five main elements.

European Council (European Urban Charter, 1992) defines city as residential area, where the human communities having common interests gather, which has autonomous administrative units and been built systematically, which offers public services, and which can manage itself.

The city is the whole of spaces, in which urban social life continues. The spaces (urban space and urban public space) are a part of the whole. In order for a city to be discussed within a whole, it is necessary to accurately define its components. The spatial and formal environment of the city develops depending not on the characteristics of elements constituting the whole of city, as well as the organization principles of these elements. This relationship can be explained with that a part contributes to the quality of whole and is affected by the qualities of the whole. The urban spaces are the structures ensuring the integration and communication of building with the city and playing a constituent role within the city. At this point, it can be stated that the most important unit establishing the relationship between building and city is the urban spaces. Madanipour (1996) analyzed the urban space by considering it from a structural frame: "we can perceive it through 1 - natural environment and its characteristics, in which it gains the first context, 2 - social context that the society transform via social processes by using the nature, 3 - historical processes referring to the fact that it is a product of the time or it emerges as a result of an accumulation throughout the time, 4 - social, physical, and symbolical aspects, 5 - its functions, 6 - spatial organization, geometries, and urban styles, and 7 - our visual experiences constituting our subjective and sensorial reactions."

With its social and physical structure, city is like a living organism. Cities have been in continuous change. Change of cities in the course of time is an inevitable consequence of nature. This dynamism also brought change and transformation in the city. Since the cities are the elements that continuously expand and change, the urban design concepts are very important for urban space. To better understand the "urban space" concept, it is also necessary to analyze the urban design concepts. Accordingly, Trancik (1986) gathered the theories related with urban design into three groups as follows. "1. Theory of solidvoid; in this theory, there is an order in form of urban voids and spaces. The urban spaces are the public monuments or official buildings, structure islands and private structures, whereas the urban voids consist of passageways between private and public spaces, intra-block spaces-inner courts, roads and squares, public parks, gardens, and landscaping elements. 2. Linkage Theory involves the organization of linking the components of the city. 3. Location Theory relies upon understanding the cultural and human characteristics of physical space. The individuals carry their own emotional necessities to the places, where they live. Thus, existence is an emotional situation rather than a physical one." At this point, the relationship between urban void and space is expected to be productive and to answer the emotional needs. In urban design, the design is approached through various characteristics of the city. Examining the urban design approaches by the criteria used in analyzing the design, Carmona (Eren, 2006) gathered these designs under 8 headings as 1 - perceptual, 2 - social, 3 - functional, 4 - sustainable, 5 - spatial, 6 - morphologic, 7 - contextual, and 8 -visual.

The urban spaces constitute an intensity enabling the people to stay together and communicate with each other. In order to better understand the subject of research, the urban spaces were divided into private and public spaces. The private spaces are the spaces belonging to the individual's own. The private and public spaces are in a cycle, in which they continuously influence each other. Erdönmez and Akı (2005) state "The spaces we use jointly for our 
private needs, the spaces we use for common location and common purposes as a member of society are defined as public space, whereas the spaces belonging to individuals and where the private needs are met are defined as private space". Stating that "when the relationship between urban voids and spaces is complete and understandable, then the spatial relationships are accurately established, the components are successfully integrated, and the character of region is constructed", Erdönmez and Akı (2005) also emphasized that the public and private spaces are the components feeding and being influenced by each other.

Habermas (1997) uses the term "public space" with physical and symbolic meanings. From the physical aspect, the public space refer to the spaces, which consist of streets, parks, and squares, where the individuals express their complaints, where the opposition to the government arises, and where the declaration for establishing a new order is made. The spaces, where the institutional idea and institutional opinion referring to the information needed for personal judgment are conveyed and where the freedom of press is guaranteed refer to the symbolic meaning of the public space. The public space is obliged to provide the instruments needed in order for the public to enjoy their freedoms.

The public space is the location of joint actions of individuals. From the spatial aspect, public spaces such as square and street are spaces, where members of society gather and share. Kostof (1999) defines public space as "a common ground, where people perform their functional and ritual activities in their normal daily routines or seasonal festivals and which link the members of society to each other" by focusing on a different aspect of the public space. The public spaces are the urban spaces, where every individual is equal to each other regardless of any discrimination. The urban spaces are those, where mutual relationships, objections, dialogues, and agreements are constructed. Weber (2000) defines public space as the place, where individuals from different social classes, races, and ethnicities gather. Considering it from the aspect of areas indicating the dimension of social life of individuals, Ferry (1994) defines the public space as a mediatic frame that represents various images of the social life to the public and establishes the technological and institutional organization of post-industrialization societies.

According to Sennett (2011), it is the tangible spaces such as squares and streets incorporating society. The society utilizes these spaces as physical, social, and symbolic instruments in order to transform or reshape the city. The public space can be considered from various aspects. Besides the social space influencing the society or gathering individuals, the spatial character is also important.

Among the urban spaces, the public spaces are spaces, where individuals are shareholders, everybody is equal before the city, the sharing exists, and togetherness is experienced. One of the most important components of public space is the squares. They are urban public spaces incorporating many characteristics of the city.

\subsection{Square as an urban public space}

The squares incorporate many spatial features. Squares are urban public spaces that have characteristics, which can be considered at different axes within the city (Figure 1). The urban public space has been defined by Eyüce (2000) by stating that "They are spaces that have expanded within residential areas consisting of physical voids and spaces. These voids, as in traditional habitats, may be a fountain or shadow of plane tree that emerges on its own through the natural development of residential area or in the light of common values accepted by everybody or the spaces that serve to entire city, have planned and regular geometry and a central character considered as a beginning point when a new city would be established". According to Tümer (2000), "urban square is a void constituted by one or more of structures "forming" the city by framing strongly or loosely and more or less. Some of the elements framing, defining, and shaping this void may be buildings, shoreline, road line, obelisk, clock tower, various trees, pools, and sculptures".

The meaning that squares incorporate has been conveyed linearly from the first cities to recent ones. Together with political approach adopted by the changing and

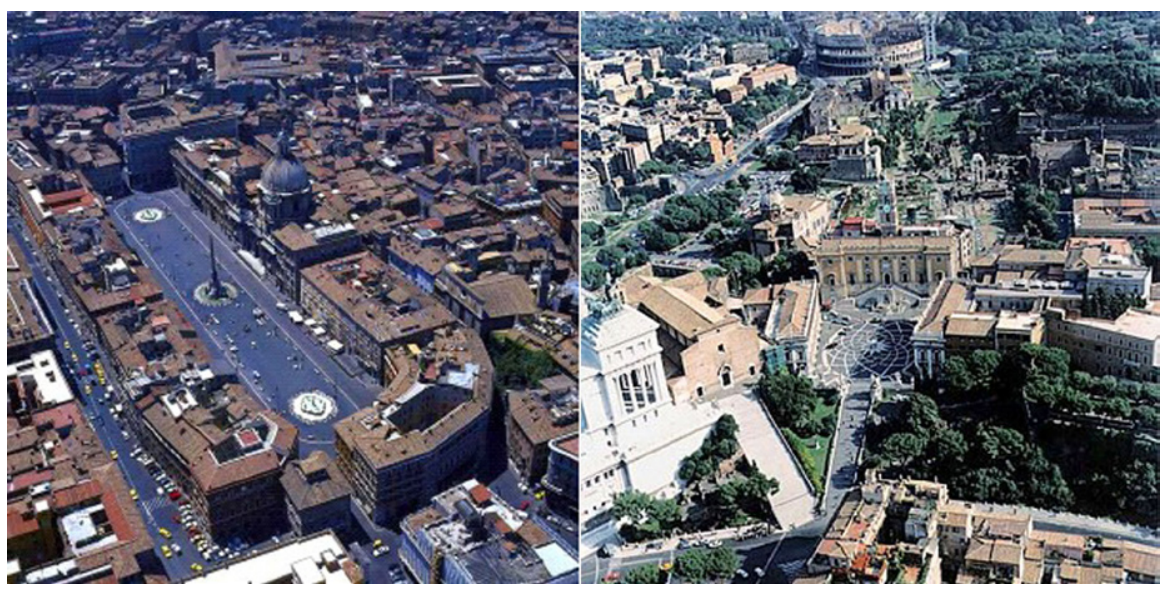

Figure 1. On the left: Navona Square, on the right: Campidoglio Square (Mimarizm, 2009) 
developing societies, the squares gained political meanings. The first action of revolting against authority is the unpermitted gathering by a mass in the squares. The public movements are called "movimenti di piazza" (which means "movement to the square") in Italy. It is one of the most important symbols of the political meaning of square. For an urbanite, the square is a place, where he/ she can feel the sharing and go without requesting permission and expressing any reason, since the establishment of first cities. Throughout history, the authorities have not only conquered the cities but also kept their finger on the pulse of squares. When an authority aims to show its power or legitimacy, one of the scenes to be chosen first is the squares. Even today, the squares are much like toiles, on which the political and social changes are engraved. From another perspective, they are the spaces, where the members of society gather for public festivals and feasts. The squares are the areas, which are handled first while organizing a city. They are the starting point for the propagation and expansion of the city. It can be clearly seen in Haussmann's Paris plan (Figure 2).

In his book "Urban Space", Krier (1979) classified the square by geometrical shapes as square, circle, and triangle. According to Zucker (1959), the ideal type of square has emerged in its best possible form in Hellenistic and

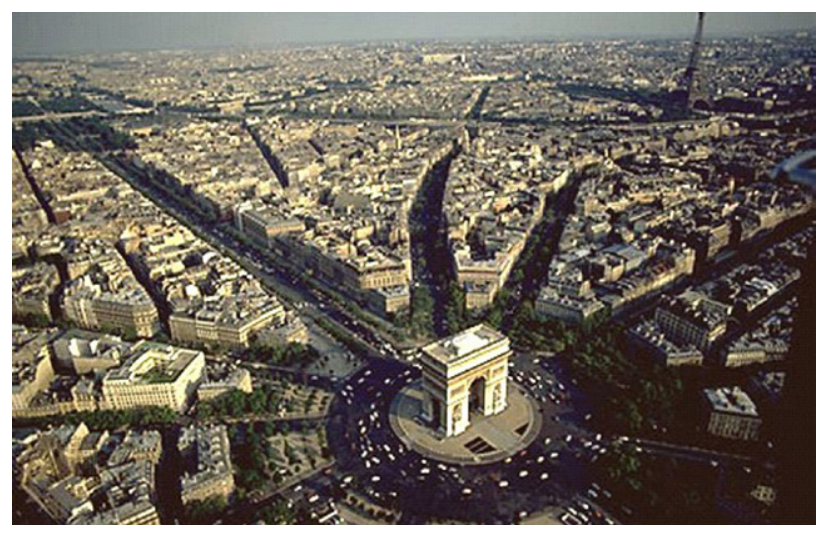

Figure 2. The appearance of Paris after the Haussmann plan (Mimarizm, 2009)
Roman ages independently from the time or architectural trends, but it has become important again in $17^{\text {th }}$ and $18^{\text {th }}$ centuries. As urban public spaces, the squares may have different physical characteristics within the city. Generally defined by the surrounding structure groups, the squares are horizontally and vertically designed and organized structures from volumetric aspect. One of the most important elements of square design is the level of surrounded space. The surrounded space depends on the heights of buildings constituting the walls or the line of streets opening to the square. Sitte (2009) claims that urban squares should have been appearance of perspective. As stated by Sitte (2009), the streets end at the edges of square so that the ones looking from the square should not see more than one street at once. In a design guideline prepared by Essex Design Guide (Essexdesign, 2019), it is stated that "The relationship between buildings' effective height and space's width is very important; when it's desired to create a consistent urban space, the sense of feeling under pressure may arise if the height is too when compared to the width or the sense of unprotectedness and exposure may arise if the width is too much." The squares should have a sufficient closure from physical aspect. In order for the buildings surrounding the square to be completely seen, the distance and openness are important (Figure 3).

The principles for designing urban spaces are very simple to explain, and an urban space has two key features: 1. degree of openness, 2. degree of interiority (Salingaros \& Pagliardini, 2016). The degree of openness of a square and how the units around it are located are important. In addition, the gaps and differentiations created at the ground level of the high-rise buildings in the square on the far right in Figure 3 show the approach to the human scale, rather than being a flat mass.

The contribution to the city of the squares located separately in the city is less than according to the squares that relate to each other in the city. "The city's circulatory system consists of the streets, the most important of which converge in the main square if the town center is small, or in the various squares if the city center is bigger, and then these will have their own specialization and obey some
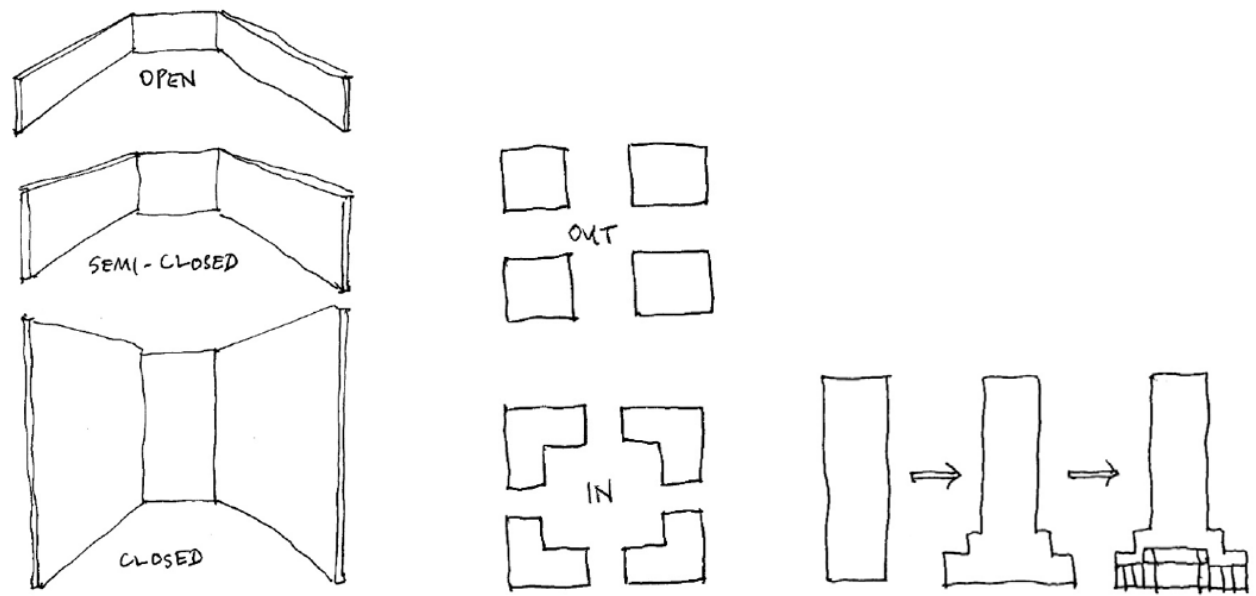

Figure 3. Urban space features (Salingaros \& Pagliardini, 2016) 
hierarchy among themselves. The public square, in order to be truly such, must lie at those network points that give the character of a node according to precise rules governing the central flows among social nodes. The nodes extend to various human activities: home, work, the green park, the store, the restaurant, the Church, etc. One of the greates problems in existing communities is the fact that the available public life in them is spread so thin that it has no impact on the community. To create these concentrations of people in a community, facilities must be grouped densely round very small public squares which can function as nodes" (Salingaros \& Pagliardini, 2016). According to Figure 4 , in a city with small squares, the square forms from the central of each node. Each node in the city is a square surrounded by spaces with a mutually appropriate mixture that strengthens itself with a certain internal dynamics. These nodes should be grouped according to function and placed appropriately both within by themselves and within the city.

"The life of a public square forms naturally around its edge. If the edge fails, the the space never becomes lively. Surround public gathering places with pockets of activity small, partly enclosed areas at the edges, which jut forward into the open space between the paths, and contain activities which make it natural for people to pause and get involved. Lead paths between the pockets of activity paths and goals and shape the pockets themselves with arcades and seats, and sitting walls, and columns and trel-
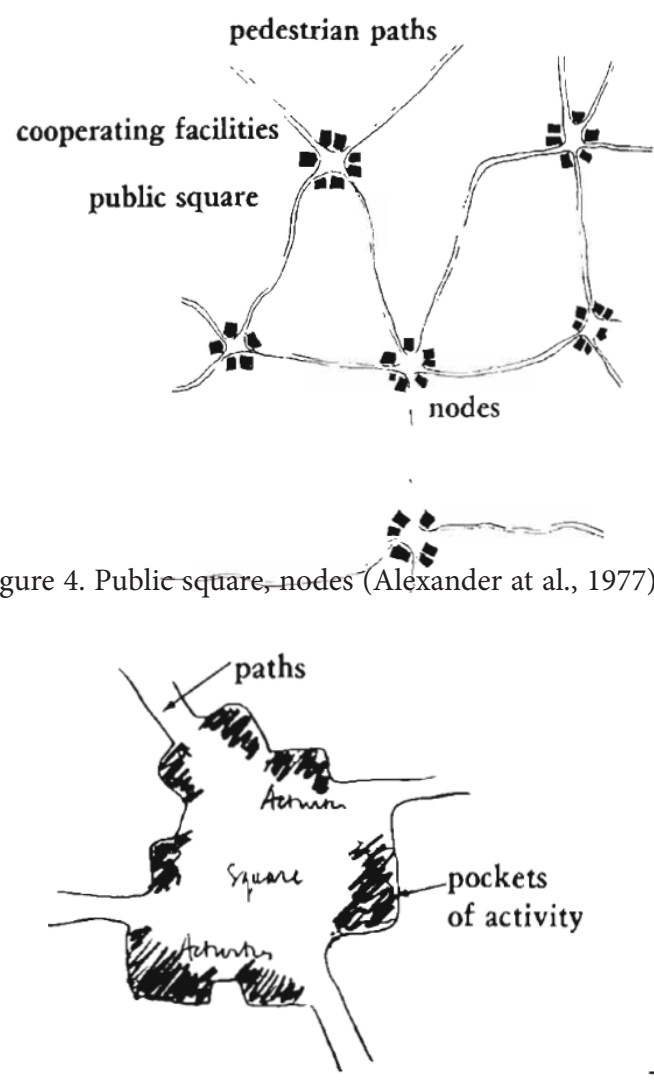

lises" (Alexander at al., 1977). When pockets with activity on the edges surrounding the square are created, the square turns into an alive space. Creating level differences with street cafes, semi-open spaces, arcades and also stairs makes it easier for people to sit and watch and spend time in the square (Figure 5).

In this article, the complexity of the holistic approach derives from the desire to make use of multiple and powerful resources, as well as handling the holistic approach in detail. Based on all these studies, the components to be used in analyzing the characteristics of a square were obtained from the conceptual studies such as space, city, urban design, private space, public space, and square:

- Historical aspect; it is emerged from the historical axis of Yücesoy (1999) in the theoretical studies section, besides that the historical continuity of Erzen (2005), together with the historical processes of Madanipour (1996). The selected square is analysed by researching according to key concepts such as history, sustainability and conservation in a historical aspect.

- Physical aspect (spatial characteristics); it is emerged from the formal and physical features they used to define the square of the Eyüce (2000) and Tümer (2000). The selected square is analysed by researching according to key concepts such as formal and spatial in physical aspect.

- Meaning aspect (symbol, image, and sign dimensions); it is emerged from the meaning and perceptual axis of Yücesoy (1999), besides that, is mantioned background and images of Lynch (1960) in the theoretical studies section, together with the square definition of Krier (1979) filled with symbolic meanings. The selected square is analyed by researching according to the key concepts such as symbol, image, and sign dimensions in the meaning aspect.

- Social aspect (society, culture, human, and politic dimensions); it is emerged from Madanipour's (1996) social concept and the social aspect of the urban space transformed by the social processes using the nature in the theoretical studies section. The selected square is analysed by researching according to the key concepts such as society, culture, human, and politic dimensions in the social aspect.

- Functional aspect (conformity to purpose and necessities); it is emerged from the definition of public and private spaces of Erdönmez and Akı (2005) mentioned in the theoretical studies section. The selected 
square is analysed by researching according to the key concepts such as conformity to purpose and necessities in the functional aspect.

- Visual aspect; it is emerged from due to Madanipour (1996) mentioned that urban space can be comprehended with visual experiences in the theoretical studies section. The selected square is analysed by researching according to the key concepts such as sensation, perception and harmony in visual aspect.

\section{Square as an urban space in today's world: approaches and practices}

In order to have a contemporary perspective, it is very important to review the recent approaches and practices regarding the city and square. It would be better to discuss the living environment before analyzing the approach to square. The problems in $20^{\text {th }}$ century, global warming as a result of collapsing natural environment, perturbation of the ecological balance, and the global events accompanying these factors have brought the elements influencing the cities and urbanites. As a result of the consumption society that has arisen together with the increasing population and advancing technology, the necessity of specific measures is discussed and the approaches are developed in this regard.

\subsection{General conjuncture in the world}

Since 1980s, most cities throughout the world have been affected by globalization. Together with cultural, technical, and commercial expansion after the globalization, the economies of cities have grown and the metropolization has arisen. The key concepts arising in globalization process were summarized by Hacısalihoğlu (1999) as speed, removal of public frame on spaces, mobility of capital, multinational companies, regional planning function, individualization, nonfunctionalism, resembling habitats, cultural closure, and disintegration from the whole. Gökgür (2008) specified the codes of globalization as follows: "1. Speed concept (the distance between spaces is now relative), 2. Differentiation of production method and mobility of capital, 3. Multinational companies, 4. Metropolitan-Global cities, and 5. Habitation." Accordingly, concepts such as metropolization, globalism, and world city have emerged as a result of globalization. The relationship of globalization processes with space brings new localities and new locations and the urban spaces disintegrate and differentiate. Another instrument used in globalization process is the cultural and natural resources specific to the locality. These resources are seen as factors improving the characteristics of the location and making it more attractive for investment. These resources turned into instruments for making a city more attractive are the images of this cycle. As a result of processes arising from globalization, the transformation of urban public spaces turned all the conventional public places serving society such as streets, avenues, squares, and parks into passage spaces. The independence being enjoyed caused the urban spaces to be considered as image without taking urban space characteristics of urban squares into account. In this period, the number of malls as public spaces gradually increases. In this process, the perspective of urban space shifted towards the shopping malls.

As a result of increasing population and rapidly consuming what exists, the concept "sustainability" became more important. Besides the ecological aspect of sustainability, also the participation and organization were discussed within the scope of social sustainability in World Conference on Environment and Development (Alada et al., 1992). Moreover, European Urban Charter (European Urban Charter, 1992) is more comprehensive and it sets important principles for creating livable environments. These subjects will be discussed in "International Agreements and Charters" section.

The squares playing role as a scene for cities are negatively affected by the globalization. The advancement of technology, especially in communication field, caused the functions of squares to start being forgotten. Sezer (2006) stated that "A series of events such as the facts that transportation and communication technologies increased physical and electronic mobility and that space has turned from depending solely on location into being related to social effects occurring at distant locations made the perspective of "abstract space" that is independent from natural rhythms and geography into a central position as main space perspective in the modern society. He also emphasized how the squares have been affected by transportation and technology. The technology making our lives easier also caused squares, public spaces, and common spaces to change. At this point, together with the new concepts, it is very important for squares to gain their old capacity.

\subsection{International agreements and charters}

The widespread urbanization turned the green areas in urban and environmental space into grey; nature is rapidly collapsing because of intense housing and the peoples are forced into a life separate from nature. The "ecological concerns" brought urban design movements. As a result of the ecological practices, the eco-city projects emerge throughout the world. These eco-cities are capable of producing their own energy and create no carbon and waste. These are self-sufficient cities.

Nowadays, the concepts of green city, eco-city, and carbon-free city have emerged. In fact, the main principle here is to create environment-friendly cities. The idea that the urban public spaces should serve for the principle of sustainability by the use of technology suggests that the urban spaces of today might be conveyed to different levels.

Many researchers and institutions (such as PPS, ULI, Spacesyntax, etc.) have made effort in order to create successful urban spaces. Project for Public Places (PPS) based in the USA is an effective NGO offering technical assistance, research, education, planning, and design proposals. It has experience of more than 1000 public space projects; 
as stated by PPS, the successful urban spaces should fulfill four main functions: "Access and Links; Purposes and Activities; Comfort and Image; and Socialization". According to PPS (Project for Public places, 2019), creating successful and high-quality cities requires ten principles, which are 1. Image and Identity. 2. Attractions and Destinations. 3. Amenities. 4. Flexible Design. 5. Seasonal Strategy. 6. Access. 7. Inner \& Outer Squares. 8. Reaching out Like an Octopus. 9. Central Role of Management. 10. Diverse Funding Sources.

The characteristics of properly functioning public spaces have been identified in Spacesyntax established in 1980s in "University College London" (Space syntax, 2019). Many researchers emphasized two main characteristics for the successful public spaces: "1. Degree of easily accessing to neighboring streets from the public space and 2. Intensity of people moving on the neighboring streets. The main principles of properly functioning public spaces are: 1 . Good accessibility to the surrounding space, 2 . Routes of pedestrians passing through the space, 3. Closeness to dense pedestrian movement, 4. Multi-perspective view to surrounding urban space, 5. Closeness of active users of space: retail and food-beverage units, 6. Sufficient sitting places and urban furniture" (İnceoğlu \& Aytuğ, 2009).

Another point coming to the forefront is quality. The quality is a concept that might be perceived differently by scientists or from different perspectives. Greene (1992) determined four main principles for the quality of space related with the design. Each main principle has four quality parameters: "1. Function. 2. Order. 3. Identity. 4. Harmony".

Nowadays, these studies and the steps taken forwards are important for the approaches related with square as an urban public space. The studies enabled the importance of urban spaces to be understood and the right of urbanite to be questioned. Besides the universal approaches, there also are international agreements and charters. European Council of Architects" (ECA) declaration titled "White Book" is an example. In 1994, the European Council of Architects started preparing a "White Book" with the theme of "Europe, Architecture, and Future". The principles of European Council of Architects can be summarized as follows (Architects' Council of Europe, 2019): 1. Quality of Life (QoF), 2. Sustainable habitat for future, 3. A European Architecture Policy, 4. Information-oriented competitive market, 5. Urban Planning, 6. Urban Design, 7. Cities as appropriate application fields, and 8. Necessity of holistic and integrated approaches to urban spaces. European Council of Architects (Architects' Council of Europe, 2019) emphasized that "a public space designed very attractively and having well-designed landscape wouldn't be used if the safety of users is not guaranteed" and stressed that the participation will be intense when approaching to the urban spaces with a holistic approach. According to ACE (Architects' Council of Europe, 2019), cooperation is very important for the high QoF in urban spaces. The comfortable, safe, and secure urban spaces designed for the urbanites are very important.
There also is European Urban Charter. Published as a manifesto for a new urbanity in 2008, European Urban Charter (European Urban Charter, 1992) emphasizes that the urbanites have below-mentioned rights: 1. Security, 2. Unpolluted and healthy environment, 3. Employment, 4. Housing, 5. Mobility, 6. Health, 7. Sports and relaxation, 8. Culture, 9. Intercultural integration, 10. High-quality architecture and physical environment, 11. Consistency of functions, 12. Participation, 13. Economic development, 14. Sustainable development, 15. Products and services, 16. Natural wealth and resources, 17. Personal integrity, 18. Cooperation between municipalities, 19. Economic structure and mechanisms, 20. Equality. According to the European Urban Charter, the cities should be places, where the individuals live comfortably, safely, and peacefully.

All these studies are steps taken to a higher QoL and saving the cities from bad conditions. In the globalized world, these agreements should not be considered as a single and standard decision because every country has a unique social, cultural, and historical structure. The studies are important for making urban space more livable. Considering the approaches to pedestrians and security in urban spaces is a positive factor. By supporting the sportive and recreational activities in urban areas, the importance of social aspects of squares and the participation character were emphasized. It was stated that the urban spaces should be used intensely also in late hours. At this point, the most important principle of these studies is the importance of holistic approach in the design of urban spaces. It was emphasized that the urban spaces would be more livable when considering them from a holistic perspective to the city-square relationship.

\section{Sampling and criteria enabling the analysis of holism of city-square relationship under today's conditions}

The approaches to city and squares in the world are presented. Through the eco-city projects prepared specifically for the cities, the environment-friendly cities are designed by considering the sustainability, ecology, carbon-free, use of natural resources, not using motor vehicles as long as possible, their recycling, and waste recycling. As a result all these steps, the concepts developed today are:

- Sustainability (ecological, economic, and cultural);

- Urban revival (urban planning, urban renewal, urban design);

- Accessibility;

- Holistic approach;

- Intercultural integration;

- Participation;

- Quality;

- Tourism;

- Mixed-use;

- Technology;

- Protection;

- Standardization. 
In parallel with the concepts specified above, the criteria set in this study are as follows (Table 1). As an analysis method, the hints in previous sections, the factors enabling the human-square integrity and the milestones in the history regarding these subjects, the selected squares were analyzed using Table 1.

Table 1. Criteria for evaluation of city-square integrity (Turgut, 2013)

CRITERIA FOR EVALUATING THE INTEGRITY OF THE CITY-SQUARE RELATIONSHIP IN TODAY'S CONDITIONS

\begin{tabular}{|l|l|}
\hline - Historical aspect & - Sustainability \\
- Physical aspect (spatial characteristics) & - Urban Revival \\
- Meaning aspect (symbol, image, and & - Accessibility \\
sign dimensions) & - Participation \\
- Social aspect (society, culture, human, & - Tourism \\
and politic dimensions) & - Mixed-Use \\
- Functional aspect (conformity to pur- & - Technology \\
pose and necessities) & - Protection \\
- Visual aspect & \\
\hline
\end{tabular}

\subsection{Trafalgar Square/England}

The Square Trafalgar has been constructed at the historical and symbolic center of London in the memory of Trafalgar War in 1805. It was designed by Sir Charles Barry as an urban space, where large masses can safely gather, and completed in 1840 . Nowadays, from the physical aspect, it is surrounded by high buildings. The building of National Gallery Museum covers one edge. There are many consulate buildings facing the square (Figure 6).

Square Trafalgar is one of the most frequently used squares of London. In $20^{\text {th }}$ century, this square turned into space intensely used and occupied by motor vehicles. In reconstruction of square in 1996, it was aimed to increase the satisfaction of visitors and the pedestrian passage. At this point, equipping the historical place with various modern activities and ensuring the balance between pedestrian and vehicle traffic are one of the main principles. The objectives of project group in Square Trafalgar are as follows (Kayalar, 2006): "1. Making space accessible and understandable by all the pedestrians, 2. Ensuring the use of all the spaces of square to a certain extent, 3. Guaranteeing the daily use by Londoners and visitors, and 4 . Providing sufficient space in the square for the ones that will benefit from the use of square."

According to Normen Foster, the architect of project, the accessibility of Square Trafalgar for the urbanites and visitors has been increased because of the removal of vehicle traffic from the face of National Gallery (Figure 7). The suggestion of Foster was to create a new center in London by organizing the pedestrian ways and motorways. From the social and functional aspect, the motorway was removed and the stairs, under which there are cafés and stores, were designed. Here, these stores played positive role in reviving the urban space. The Nelson Monument and decorative pools at the center of square contribute to the urban space from the visual aspect (Figure 8). The square has its own webpage and announcement of events contributes to participation.

\subsection{Bryant Park/U.S.A}

In 1884, Bryant Park was renamed Bryant Park, to honor the poet, editor of the New York Evening Post and civilian reformer, William Cullen Bryant (1794-1878), while his name was Reservoir Square. The New York Public Library was designed on one side of the square by architects John Merven Carrere and Thomas Hastings, and the square was completed in 1911 with the Beaux-Arts building, the library's back terrace and the east end of Bryant Park (Figure 9).

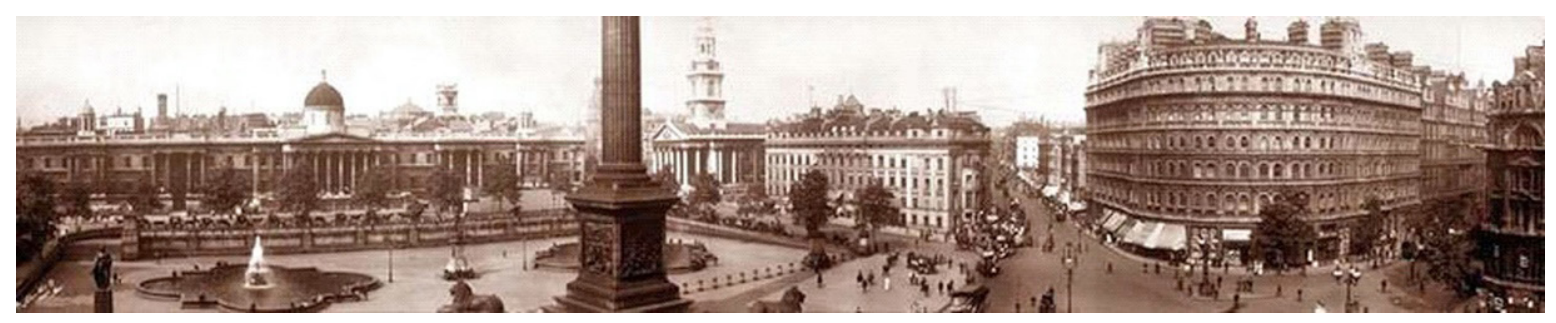

Figure 6. Trafalgar Square (London assembly, 2019)

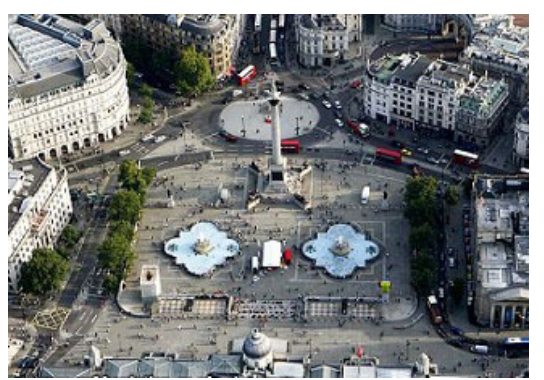

Figure 7. Trafalgar Square (London assembly, 2019)

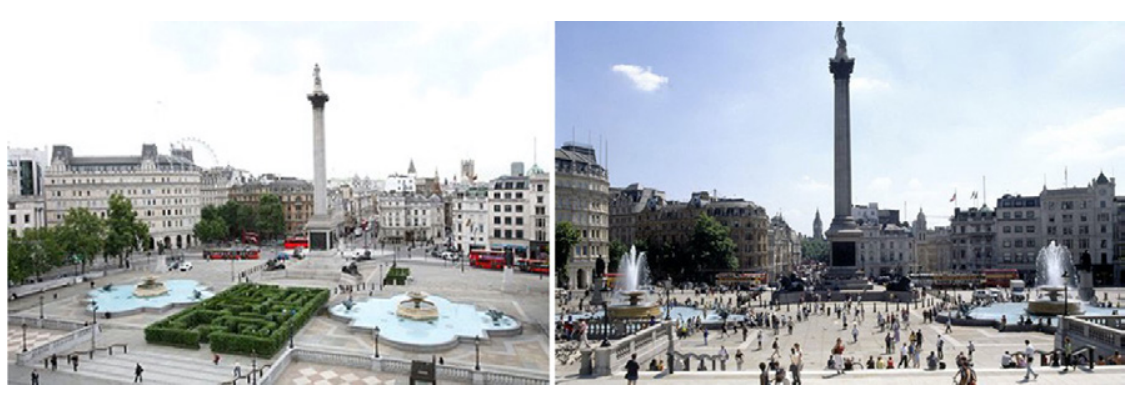

Figure 8. Trafalgar Square (London assembly, 2019) 
After the demolitions in the 1930s, a competition was organized to redesign the square, and it was reopened on September 14, 1934. This has showed that in Bryant Park, especially in the 1930s, that the squares can be reconsidered and passed through certain correction steps according to the conditions of the day. With the arrangements made, the physical, meaning, functional and visual aspects of the square have completely changed.

With the new regulations, the square became an open reading area serving the New York Public Library (as it was called in the 1930s; Central Bryant Park Library) (on the right, Figure 10). Bryant Park, which is physically surrounded by means of vehicles, and by skyscrapers, there is a historical library on the east side of it and has a rectangular form is surrounded by trees with a large green area in the middle (Figure 11). Approximately, it is two meters higher than the busy streets around it, so the level of the street is reached by the stairs at the edge of Bryant Park.

At the end of the 1980s, Bryant Park transformed from an urban location with high crime rates to an urban location where social activities took place with the work done. With the reorganizations between 1988 and 1990, the square had safe, publicly visible entrances, a large green area, and closed wet areas. After the arrangements, the average number of people at noon reached 4000 on a sunny day, and the annual number of visitors doubled (Bryant Park, 2020). Accordingly, it is a positive square in terms of participation (Figure 12). Fortunately, the meaning, image and symbol size of the square has changed with urban arrangements.

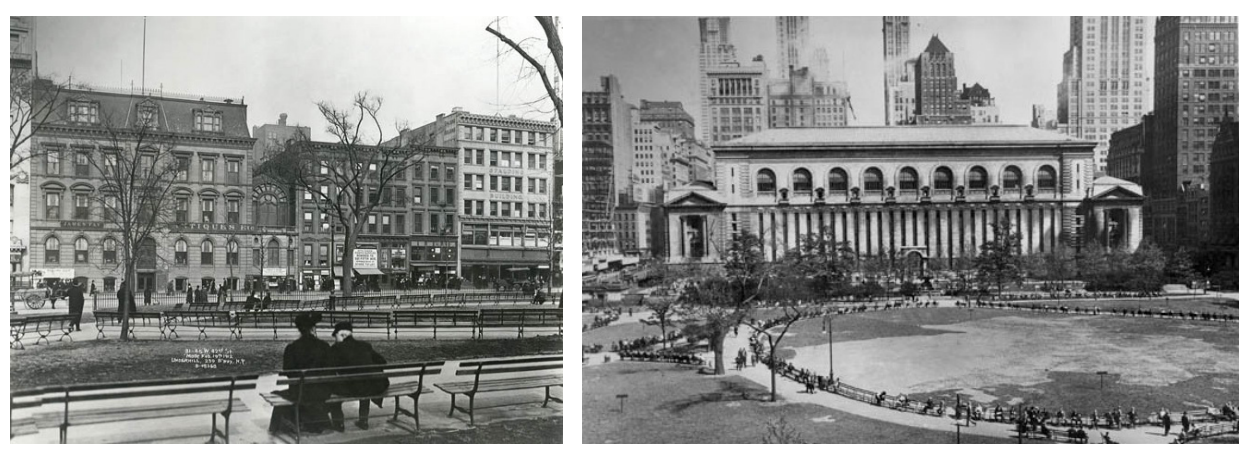

Figure 9. Bryant Park, 1910s (Bryant Park, 2020)
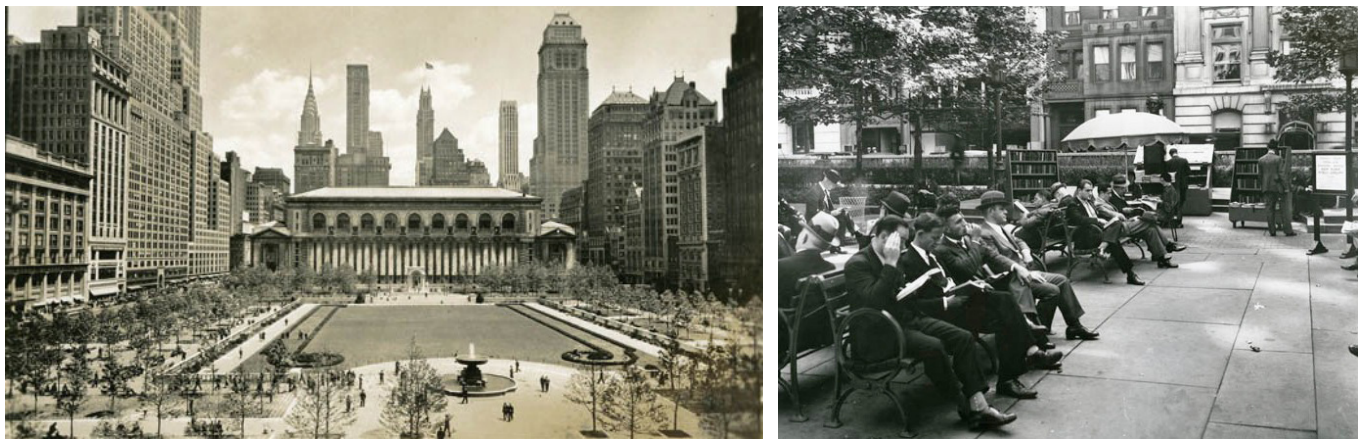

Figure 10. Bryant Park, 1930s (Bryant Park, 2020)

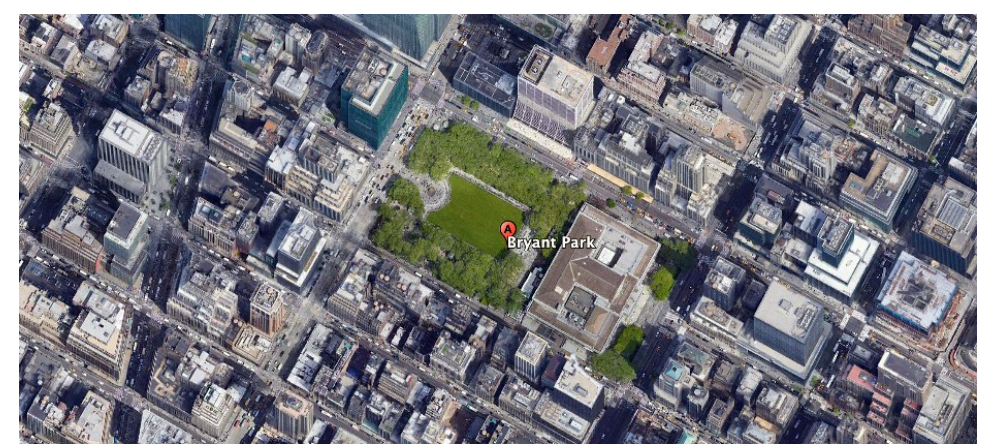

Figure 11. Bryant Park (Google Earth, 2020)

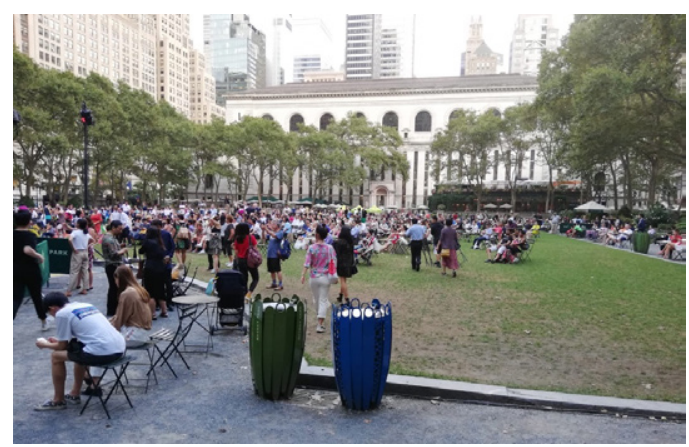

Figure 12. Bryant Park, 2019 (source: author) 


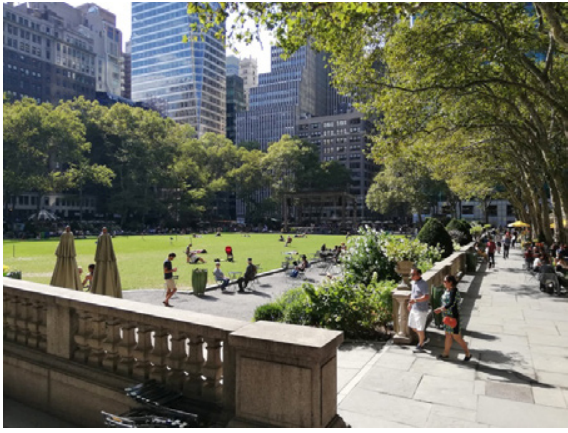

Figure 13. Bryant Park, 2019 (source: author)

It is visually green and has a gray coating on the ground where people sit, the historical structure and the stone coating of the terrace and stairs of this building on the park side and the cream color of the railing created a harmonious continuity (Figure 13).

It is also seen that this area between skyscrapers is alive and dynamic throughout the day. On the square, open-air cinema, yoga and ice skating activities are held all year round, and public participation is supported throughout the year (Figure 14). The historical library located in the east of the square, the events organized, the trees preventing intense vehicle traffic and noise around it, and the difference of about two meters codes from the street increased the vitality of the square (Figure 14).

\subsection{Istanbul Taksim Square/Turkey}

Istanbul is a city that has been the capital of the Byzantine and Ottoman Empire. Taksim Square, which is the stage of Istanbul, was named XVIII. It took its name from the water distribution network built in the 18th century. The square is located at the intersection of Istiklal Street, Siraselviler Street, Gümüşsuyu Street, Cumhuriyet Street and Tarlabaşı Boulevard within the boundaries of Beyoğlu district. In the 19th and early 20th centuries, like many cities not found in the Western world, it remained open to the cultural and physical impact of Europe in Istanbul (Çelik, 2016). Istanbul experienced the impact of collective efforts to turn it into a Western-style capital city in the 19 th century. While Beyoğlu progressed with the feature of a European city under the influence of the West, it made the Taksim more convenient in terms of transportation with the arrival of the electric tram in 1913 (Dökmeci \& Çıraci, 1990). The tram route built in this period positively affected the accessibility of the city and the square. The electric tram route built in the early 20th century was also effective in determining the square form.

In the reconstructed arrangements in the early Republican period, along with planned zoning movements, in 1928, the Taksim Republic Monument was built by the Italian architect Cononika, and the barn and warehouse buildings in the south of the barracks were demolished during the square arrangement. During these arrangements, when a new stadium (İnönü Stadium) was built in the area where the stables belonging to Dolmabahçe

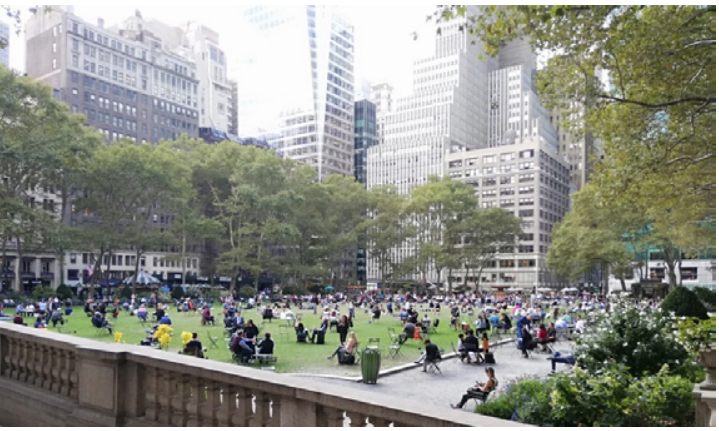

Figure 14. Bryant Park, 2019 (source: author)

Palace was built, the courtyard of Taksim Barracks was also freed from hosting sports events (Cezar, 2002). The area around the monument was arranged as a ring to accelerate the traffic flow with a ceremony area (Karaman \& İşözen, 1987). The barracks were gradually demolished during Lütfi Kirdar's mayor's office in 1940 upon the proposal as green of the area where the barracks were located and the approval of this plan by the municipality during the activities within the scope of the works for creating the zoning plan of Istanbul, which was started under the coordination of Henri Prost (Çelik, 2015). Taksim Square has come as a project designed to French architect Henry Prost under the leadership of Lütfi Kırdar, the governor of Istanbul at the time. This project covers the valley between Taksim and Maçka, where Taksim Trip is included, starting from the square. Thus, a green belt was tried to be created between the historical city center and the newly developing districts of the city at that time. Taksim Square was formed as a result of the arrangements made on the demolition of the Taksim Barracks in the continuation of the project of the Republic Monument first and then the Architect Prost (Figure 15).

In terms of accessibility until 2013, the square was in the traffic center duty due to reasons such as the starting point of the metro, the offices of intercity buses and airport companies, the presence of the first and last stops of the city buses (Figure 16). It is a crossroad that serves vehicle traffic more than urban public space features and was in a pedestrian and vehicle complex.

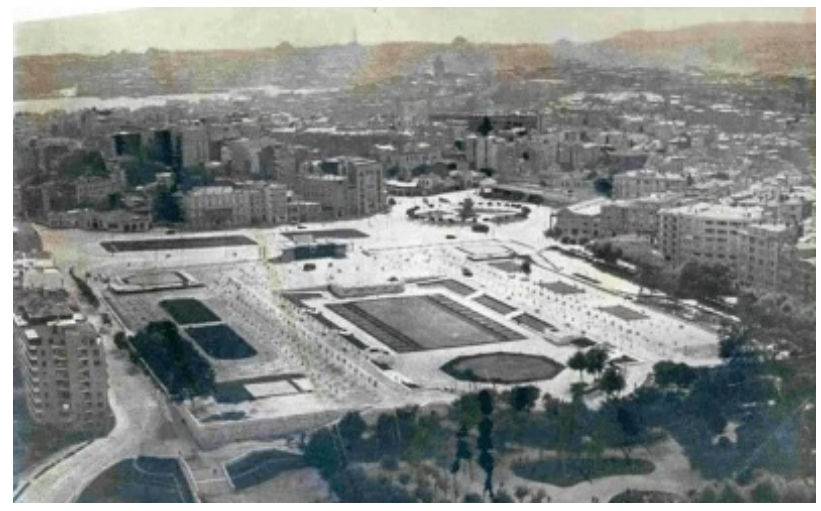

Figure 15. Taksim Square, 1940s (Güzelleşen İstanbul, İstanbul Belediyesi, 1943; Gül et al., 2014) 

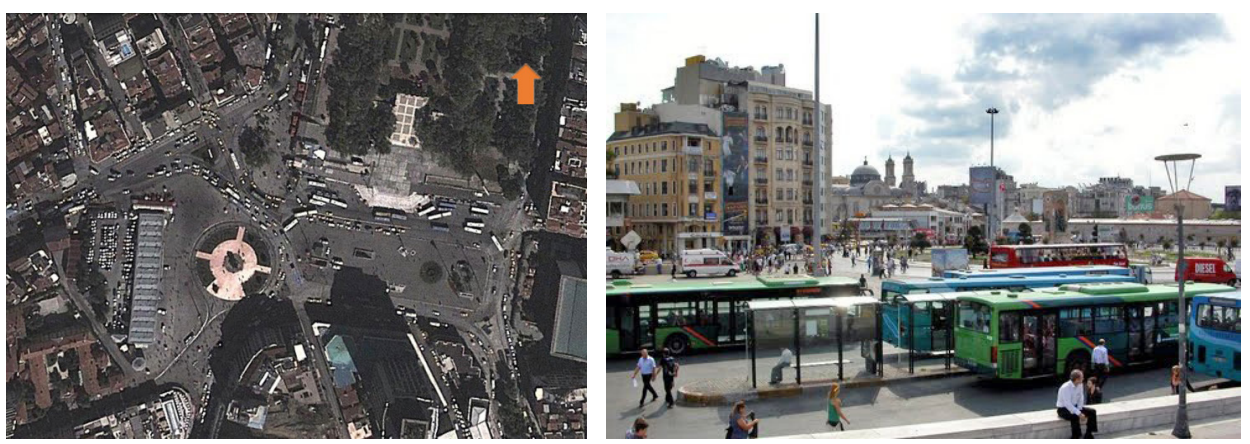

Figure 16. Taksim Square was the traffic node in 2013 (Turgut, 2013)

Today, it has a feature that evokes a different perception from every point in terms of physical size. The degree of closure formed by the borders of the square remains weak, its relationship with the park cannot be established and there is no specific form. With the last arrangements, the roads leading to Taksim Square have been underground. In the west of the square, where the streets meet, there is the Atatürk monument (1928) with its circular landscape and pink floor covering. In the north of the square, there is a rectangular form of Gezi Park and the team built with a competition project at the corner of the park includes the InterContinental Hotel (1958-1974), which is the design of the AHE architecture office, which includes Kemal Ahmet Aru. It is connected to the square with stairs at the edge of Gezi Park, which is about four meters higher than the square. The construction of The Marmara Hotel (1976) on the south of the square, the new Cultural Center on the east and the new Mosque on the west continue (Figure 17).

Taksim Square is a square that has hosted important events throughout the history of the Republic (Figure 18). We remember the labor movement of May 1, 1977 and the traces of the 1980 coup from this square. Taksim Square was also remembered with Gezi Park events in 2013. It is the protest events that started with the idea that the new barracks as one of the new arrangements to be made in the square design in Gezi Park will destroy the green. After protests, the Gezi Park has been left as green by giving up the new barracks project. Taksim square is a triangulation point in terms of meaning (image, symbol, sign aspect). The meeting places of people are the monument in the square or the shop structures located around it, and today it is a square with symbolic features.

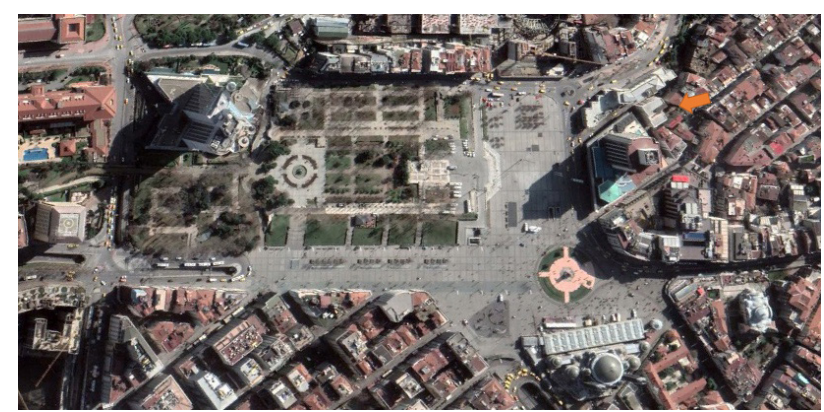

Figure 17. Taksim Square (Google Earth, 2020)
Visually, there is a gray basalt stone on the floor and a pink stone coating around the Atatürk Monument. It is located in green around Gezi Park and Atatürk monument. Today, an international Taksim urban design competition is organized by the Istanbul Metropolitan Municipality Cultural Heritage Department. With the continuing new arrangements, the holistic assessment of the square should be reconsidered over time.

Taksim Square is a crowded square in terms of participation. Every hour of the day has a certain intensity (Figure 19). Istiklal Street, the wide pedestrian road in the south west of the square, which is connected to the square with shops and cafes on both sides, increases the density. Due to the shops, cafes, religious and historical buildings, consulates, hotels around the square, the square is a place

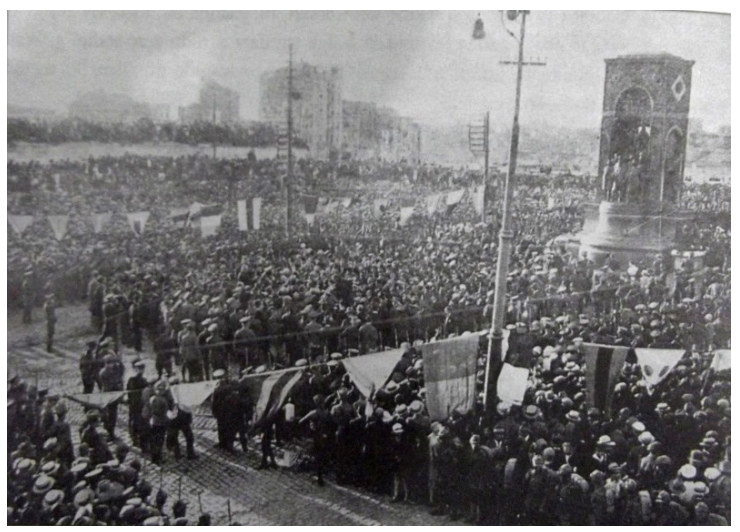

Figure 18. A ceremony in Taksim Square, Cengiz Kahraman archive (Kuruyazıc1, 2014)

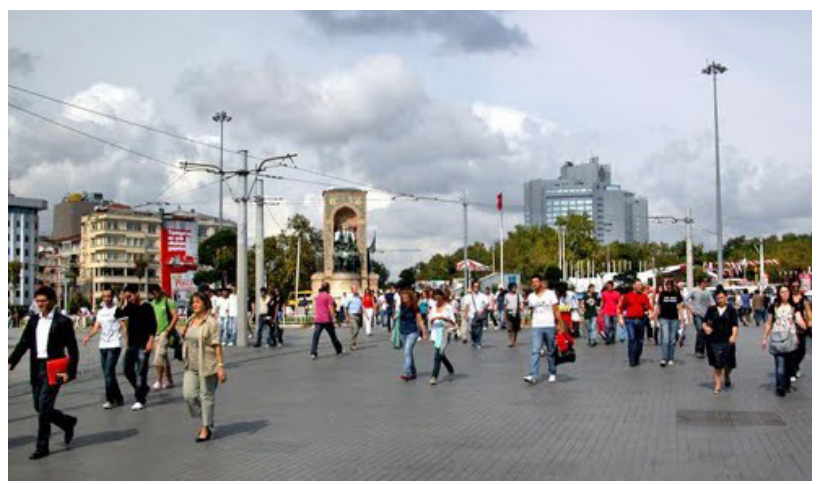

Figure 19. Taksim Square 
that lives every hour of the day where activities such as shopping, socializing, spending time and eating are carried out. Gezi Park, which is located in the square today, is not a safe park used extensively, especially in terms of security after a certain time of the day. Activities for public participation are not carried out in the park. On certain days, the west of Gezi Park on the street opening to square, is organized exhibition and sales units with prefabricated tent materials. In the east of the square, in front of Gezi Park, the exhibition, gathering, and event structure, which has a platform created with stairs in different directions called gathering stop, also added movement to the square. Temporary interchange stops that increase participation will be moved to a park to be selected in Istanbul at the end of the international Taksim urban design competition.

\section{Conclusions}

Examining the characteristics of the urban public space, which is an important element of city, it can be seen that it has various functions within the city. However, most of the urban squares are not gradually losing their historical, physical, meaning, social, functional, and visual characteristics.

The modernity project developed after the Industrial Revolution has brought changes in city, squares, and many other fields. Together with the Industrialization Revolution, also the environment of humans has changed. The muscle strength has been used in the production by small ateliers where the factories using the machines carry out standard and faster production at higher amounts without needing human labor. The structure of society has changed and thus the city and square have changed. With the use of technology, the rails, metros, bridges, and vehicles have been manufactured. The motor vehicles introduced to our lives together with technology started a new period. Besides the changes brought by motor vehicles, also various problems such as accessibility of urban space have emerged. The urban spaces, which have been constructed without considering the motorways, were turned into enlarged cross-roads. In this period, we are side-byside but not together in the squares; we use the squares together with motor vehicles.

Today, the concepts of city, urban space, public space, and square are considered together with new concepts. Because of the consequences of globalization, urban spaces are the images of cities and they are considered as intense investment instruments. Together with this process, new projects are prepared for the squares. In urban revival project practices, it was aimed to analyze the relationship between square and buildings surrounding the city center in details, ensure the connection of entrances of constructed buildings to the square by making use of attractive and inviting platforms at different elevations, resolving the inner courts opening to the square between the office blocks, and revive the urban public life with various activities. Moreover, in the example, it can be seen that the accessibility problems of squares were considered with a holistic approach. As seen in the analyzed example, the works aiming to revive the urban space have been designed within the city-square integrity and the positive outcomes were achieved. Technology, sustainability, ecology, and attitudes and opinions regarding enriching the urban public space are important for the function, use, and future of today's city.

According these results, within the context of criteria (Table 1) enabling the analysis of the integrity of citysquare relationship under today's conditions, although a square is analyzed from historical, physical (spatial), meaning (symbol, image, and sign), social (society, culture, and human), functional, and visual aspects, also the sustainability, participation, tourism, mixed-use, technology, accessibility, urban revival, and protection factors should also be used in analyses.

As a result:

- Historical aspect: Trafalgar Square, Bryant Park and Taksim Square are not newly designed squares, they are squares subject to regulations in the historical process. The fact that the library built in Bryant Park at the end of the 19th century can be preserved and survived among the skyscrapers shows the importance of handling a square with its historical aspect. The stratification in the square, which occurs over time with certain admissions, depends on the protection of elements such as structure, tree, road in a square.

- Physical aspect: Taksim Square has been pedestrianized, but it has no specific form, borders, and has not been linked to Gezi Park in the north east of the square. Bryant Park is in a simple form among the skyscrapers. In Trafalgar Square, it is important to create floors at different levels with stairs. Creating floors at different levels in a square, like dividing a house into rooms, divides the square into sections, and using the square at different levels has a positive effect on the degree of enclosure of the square. Creating activities in pockets, which you can find in different levels rather than on a flat floor, also changes positively the square.

- Meaning aspect: Taksim Square stands out with its meaning aspect compared to other squares. The fact that the main streets such as Istiklal Street connected to the square, has strengthened the meaning aspect of the square, beside the important events in the past. The combination of structures with multiple functions in a square and a wide and dense pedestrian path connected to the square also facilitates the meeting to be a triangulation point. The pedestrian and lively main roads connected to the square also feed the square.

- Social aspect: The presence of the library on the edge of Bryant Park, the protection of the green area and the activities organized have increased socialization. Activities created to spend time in the square, 
semi-open, open spaces in nature created contribute to the social aspect. Eventually, in Bryant Park, it has been transformed into today's conditions without much intervention by using nature.

- Functional aspect: At the Trafalgar Square, the toilets that are solved due to the difference in elevation contribute to the functional aspect, and the green areas in Bryant Park create a comfortable resting place in terms of the functional aspect. The code difference around Bryant Park also distinguishes the square from heavy vehicle traffic.

- Visual aspect: Taksim Square is reorganized with an urban competition project. The Gezi Park in Taksim Square can bring many positive features in terms of visual. Stairs, ornamental pools and sculptures are homogeneously located in Trafalgar Square, and Bryant park is mainly in green. The floor covering color in a square, the coating color of the stairs that appear with elevation differences, ornamental pools, green areas, the color of the structures forming the edges of the square should be in visual harmony.

A square should be analyzed according to all these criteria and together with the integrity of city. The squares, which are urban spaces, should be considered within the integrity of city and in cooperation between public and private spaces. The squares should be examined from a holistic perspective to city-square relationship and the regulations should be made in this parallel. So the place of squares in the pattern of city can be maintained.

\section{References}

Alada, A. B., Gürpınar, E., \& Budak, S. (1992). Rio konferansı üzerine düşünceler. Dergipark. https://dergipark.org.tr/download/article-file/5549

Alexander, C., Ishikawa, S., Silverstein, M., Jacobson, M., Fiksdahl-King, I., \& Angel, S. (1977). A pattern language. Town, buildings, construction. Oxford University Press.

Architects' Council of Europe. (2019). An organization that ensures Europen architecture and professional policy. Brussels. https://www.ace-cae.eu

Barthes, R. (1997). Göstergebilimsel serüven (Çev. Mehmet Rıfat, Sema Rifat). Yapı Kredi Yayınları.

Bryant Park. (2020). https://bryantpark.org

Cezar, M. (2002). Osmanlı başkenti İstanbul. Ekav Vakfı.

Çelik, Y. (2015, Mayıs 25-26). Mit ve gerçek arasında: Taksim Topçu Kışlası (Beyoğlu Kışla-i Hümayunu). In Osmanlı İstanbul'u III, Uluslararasi Sempozyum (pp. 443-476), İstanbul 29 Mayıs Üniversitesi. http://osmanliistanbulu.org

Çelik, Z. (2016). 19. Yüzyılda Osmanlı başkenti değişen İstanbul. İş Bankası Kültür.

Dökmeci, V., \& Çıracı, H. (1990). Tarihsel gelisim süreci içinde Beyoglu. Türkiye Turing Ve Otomobil Kurumu.

Erdönmez, M. E., \& Akı, A. (2005). Açık kamusal kent mekânlarının toplum ilişkilerindeki etkileri. Megaron, 1(1), 67-87.

Eren, İ. Ö. (2006). Mimarlıkta tasarım yer ilişkisi bağlamında “yer"e özgü mimari dilin dönüşüm sürecinde yeniden üretilmesi [Doktora tezi]. Mimar Sinan Güzel Sanatlar Üniversitesi/Fen Bilimleri Enstitüsü. İstanbul.
Erzen, J. (2005). Kent estetiği ve kültürel kapsam. In Afife Batur'a armağan (pp. 327-333).

Essexdesign. (2019). Is about building communities and making sure that the infrastructure and facilities are in place at the right time. https://www.essexdesignguide.co.uk

European Urban Charter. (1992). European Urban Charter was declareted in 1992 Council of Europe.

https://rm.coe.int/168071923d

Eyüce, Ö. (2000). Meydanlar. Ege Mimarlı, 34(2).

Ferry, J. M. (1994). Philosophie de la communication 2. Cerf.

Google Earth. (2020). Google Earth Pro. Google LLC. ABD.

Gökgür, P. (2008). Kentsel mekanda kamusal alanın yeri. Bağlam.

Greene, S. (1992). Cityshape: communicating and evaluating community design. American Planning Association, 58(2), 177-189. https://doi.org/10.1080/01944369208975792

Gül, M., Dee, J., \& Cünük, N. (2014). İstanbul's Taksim Square and Gezi Park: The place of protest and the ideology of place. Journal of Architectre and Urbanism, 38(1), 63-72. https://doi.org/10.3846/20297955.2014.902185

Habermas, J. (1997). Kamusallı̆̆ı yapısal dönüşümü. İletişim Yayınları.

Hacısalihoğlu, İ. Y. (1999). Küreselleşme, mekânsal etkileri ve İstanbul [Yüksek lisans tezi]. Mimar Sinan Güzel Sanatlar Üniversitesi/Fen Bilimleri Enstitüsü, İstanbul.

İnceoğlu, M., \& Aytuğ, A. (2009). Kentsel mekânda kalite kavramı. Megaron, 4(3), 131-146. https://www.journalagent. com/megaron/pdfs/MEGARON_4_3_131_146.pdf

Karaman, A., \& İşözen, E. (1987). Taksim ve yakın çevresi tarihsel gelişimi (Taksim meydanı proje yarışması kitabı). İstanbul Büyükşehir Belediyesi.

Kayalar, J. (2006). Kent ve meydan olgusu-yeniden canlandirma sürecinde karşılaştırılmalı bir irdeleme [Ms thesis]. M.S.G.S.Ü. Fen Bilimleri Enstitüsü, İstanbul.

Kostof, S. (1999). The city assembled. Thames and Hudson.

Krier, R. (1979). Urban spaces. Academic Editions.

Kuruyazıcı, H. (2014, Ocak-Mart). Cumhuriyet'in İstanbul'daki Simgesi Taksim Cumhuriyet Meydanı. İTÜ Vakfı Dergisi, 63, 28-34. http://ituvakif.org.tr/dergi/sayi_63.pdf

London assembly. (2019). Ensures the Mayor' policies. https:// www.london.gov.uk/about-us/our-building-and-squares/ trafalgar-square

Lynch, K. (1960). The image of the city. The MIT Press.

Madanipour, A. (1996). Design of urban space: an inquiry into a socia-spatial process. Wiley.

Mimarizm. (2009). Mimarlik yayın platformu. http://www.mimarizm.com/haberler/paris-e-haussmann-plani-ndan-sonrarogers-plani_116365

Montgomery, J. (1998). Making a city: urbanity/vitality and urban desing. Journal of Urban Design, 3(1), 93-116. https://doi.org/10.1080/13574809808724418

Project for Public places. (2019). Amerika Birleşik Devletleri merkezli kamusal mekânlar için proje şirketi PPS dir. http:// www.pps.org.tr

Salingaros, N. A., \& Pagliardini, P. (2016, July 6-8). Geometry and life of urban space. In 11 th Congress Virtual City and Territory, Krakow.

Sennett, R. (2011). Ten ve taş batı uygarlı̆̆ında beden ve şehir. Metis Yayınları.

Sezer, D. (2006). Mahremiyetin despotlukları: kamusal insanın çöküşü üzerine bir deneme. http://www.korotonomedya.net/ kor/index.

Sitte, C. (2009). Hegemann and the metropolis: modern civic art and international exchanges. Routledge Print. 
Space syntax. (2019). Academic development. http://www.spacesyntax.net/academic-development/

Trancik, R. (1986). Finding lost space: theories of urban design. John Wiley and Sons.

Turgut, D. (2013). Kent - meydan ilişkisine günümüz koşullarında bütünsel bir bakış: Türkiye özelinde bir değerlendirme [Yüksek lisans tezi]. Mimar Sinan Güzel Sanatlar Üniversitesi/Fen Bilimleri Enstitüsü, İstanbul.

Tümer, G. (2000). Kentler, binalar, insanlar, olaylar, meydanlar. Ege Mimarlik, 2-34.

Urry, J. (1999). Mekânları tüketmek. Ayrıntı.

Yücesoy, E. Ü. (1999). Kentsel tasarımda mekansal kimlik tartışmaları üzerine bir değerlendirme: Mekansal kimliği okumak (I. Ulusal Kentsel Tasarım Kongresi Bildiriler Kitabı). Mimar Sinan Üniversitesi, Mimarlık Fakültesi, Şehir ve Bölge Planlama Bölümü Yayını.

Weber, M. (2000). Sosyoloji yazıları (Çev. Taha Parla). İletişim.

Zucker, P. (1959). Towns and square. Columbia University Press. 